Journal of Awareness

Cilt / Volume 5, Say1 / Issue 4, 2020, pp. 527-534

E - ISSN: 2149-6544

URL: https://journals.gen.tr/joa

DOİ: https://doi.org/10.26809/joa.5.037

Araştırma Makalesi / Research Article

\title{
CULTURAL TOURISM OF MONTENEGRO ${ }^{1}$
}

\author{
Nikola M. VUKČEVIĆ* \& Nina VUKČEVIĆ***
}

* Teaching Assistant at Faculty of Arts and Communication,

University of Donja Gorica, Podgorica,

MONTENEGRO,e-mail:nikola.vukcevic@udg.edu.me

ORCID ID: https://orcid.org/0000-0002-0515-0353

** PR Manager of National Tourism Organisation of Montenegro,

Ministry of Sustainable Develompent and Tourism of Montenegro,

MONTENEGRO,e-mail: nina.vukcevic@montenegro.travel

ORCID ID: https://orcid.org/0000-0001-9974-527X

\begin{abstract}
In this paper the proposed approaches to the management of cultural tourism and tourism in general are considered. The first is a review of the historical context of cultural tourism, and, through the collection of the opinions of numerous authors, an overview of the concept itself. Then there was a parallel between broken concepts, culture and tourism, and synergy and networking of these two terms. Furthermore, Montenegro is taken to be the study case, as country which has been recognizable in previous years, as one of the prosperous tourist countries in the region and beyond. Montenegrin cultural tourism and tourism in general were analyzed since the restoration of Montenegrin independence in 2006. The SWOT method was used, the application of which were obtained qualitative results that define the guidelines and suggestions for further development of cultural tourism and tourism in general in Montenegro.
\end{abstract}

Keywords: Culture, tourism, cultural tourism, tradition, Montenegro. 


\section{INTRODUCTION}

First of all, it is very important to emphasize that the topic is extremely broad and that the purpose of this analysis is to inspire other authors to carefully study this complex and broad issue. Thus, a general approach is made in the paper and certain results are obtained that represent a segment of this massive topic.

The paper primarily looks at the historical context of cultural tourism itself and tourism in general. As in most things, the focus of collecting the first historical facts, which testify to the existence of a certain type of cultural tourism and tourism in general, is in ancient times. Of course, for this to be interpreted, it is necessary to move into the context of that time. Opinions from various authors have been collected, with some reflecting on the pre-Columbian period and some cultural tourism and tourism in general being studied in the postmodern era. The collection of numerous analyzes by these authors was intended to facilitate our understanding of this phenomenon today.

The paper draws a parallel between the various concepts, culture and tourism, and gives an overview of the networking of these two concepts into one - cultural tourism.

Using the well-known and affirmative method, SWOT analysis, a qualitative research of Montenegrin cultural tourism has been made since the restoration of Montenegrin independence in 2006. In this way, proposals for further development of cultural tourism and tourism in Montenegro in general were defined.

\section{METHODS}

SWOT analysis unifies 4 groups of parameters in one place and points to their connection. By combining the parameters, we get a clearer picture of the position of the organization and more easily arrive at a solution to the problem of choosing a strategy in the upcoming situations. So in SWOT analysis:

- strength is the capacity that an organization currently has and can use to achieve its goals;

- weakness is the lack of an organization that prevents it from achieving its desired goals;

- opportunity is one or more promising situations in the organization's environment;

- threat is one or more possible adverse situations in an organization's environment.

This managerial method is implemented on two levels (Perović 1998: 147):

The first level refers to the collection and systematization of the basic factors from the organization and its environment that affect the functioning of the business system. At this level, facts about the market, competition, financial resources, equipment, employees, inventories, management, etc. are collected.

The second level aims to put the facts gathered in relation to the capabilities, dangers, potentials and weaknesses of the organization.

After forming a matrix, it is necessary to consider it from several angles: how to take advantage of the advantages, consider the possibility of overcoming the weaknesses, locate the possibility to maximize the opportunities provided, find a way to minimize threats (Vujović, Perović, Krivokapić, Jovanović 2014: 248). 


\section{CULTURAL TOURISM THROUGH HISTORY}

The period of ancient Rome is known for the fact that people have already visited places where traces of older cultures and civilizations were found. One of the more important reasons people traveled, especially in the 17th century, was the acquisition of a higher level of education. These journeys were characteristic of the life of the aristocracy at the time, but later it became the custom of the middle class. In the second half of the 19th century, the term "attraction" appeared for the first time. The understanding of this concept was related to what is extremely attractive and creates the influx of a large number of tourists to a particular place (Pančić 2006: 215). The motivation for travel, until the First World War, gave the cultural contents of cities, so their visits were extensive. Unfortunately, during the war period a large number of cities were destroyed, and with them their culture. Little was taken of it, since the existence was threatened during those war years. Tourism, and culture, are gaining momentum after the Second World War. At that time, culture was still scarce, and tourism was no longer reserved for a privileged group of people, it became mass consumption, and later one of the most promising forms of employment in the world. It is conditioned to become one of the world's leading industries (Vukonić 2008: 111-122).

More precisely to talk about the beginnings of cultural tourism or even to determine the exact period of its creation, objectively, is not possible for several reasons. First, each trip can be characterized as a cultural one because the traveler, intentionally or by accident, must come to know the cultural customs and the elements by coming to another place. Second, and in the pre-Columbian era people traveled and, in some way, were cultural tourists. A trip was then a privilege reserved for the rich, which is the main motive of the trip was warfare, the spread of the faith, but also exploring different destinations and cultures. Increasing the level of education and the possibility of good earnings, by the end of the 20th century, have contributed significantly to the emergence of the postmodern tourists. This type of tourist could organize his trip with a clear, pre-determined goal. In this place, he does not expect a break, but actively develops his own interests, complemented by local differences, which refines and allows progress to his existing knowledge (Jelinčić 2008: 52-53).

\section{THE RELATIONSHIP BETWEEN CULTURE AND TOURISM}

The notion of cultural tourism, both in theory and in practice, should be viewed through the interaction of its parts, so it will be perceived very broadly and will include numerous aspects of life and human activity. Reflecting on culture, it needs to be broadly defined, in order to include the links that keep it connected with tourism. Culture, in this case, gets the form of a process (escapes from static and immutability), and tourism, by its dynamism, contributes to both of them continually changing. Greg Richards believes that culture, as one complex whole, is based on the concept of a broad spectrum of lifestyles. The reason is that it does not cover only the material forms of a culture of an environment, but also the daily interaction on the guest-host relationship, which means that it constantly creates the exchange of cultural elements (Richards 1996: 266).

It could be said that language brings together modern nations, and culture remains to distinguish them. In this, on the one hand, there is the possibility of mutual understanding, and on the other hand - the beauty of diversity (Gačev 2011: 14). It is precisely this beauty of diversity that is realized through tourism, as a segment in which there is a collision of cultures and the exchange of their contents. It is inevitable that culture is a prerequisite for the development of tourism, but also tourism plays an important role in all of this - it valorizes culture. Montenegro, as a country that until recently had developed a large corpus of economic activities, has a tourism in the 21 st century as the primary prosperous economic branch. The fact is that culture and tourism are tightly connected today. In this relation, it is desirable that 
the result is cultural tourism, and not a tourist culture, which may be a strategic mistake in the case of Montenegro.

It is characteristic for tourists that, when they are not in their place of residence, are more relaxed, they pay less attention to the opinion and perception of the environment about them, they dress more casually, etc. However, this application of commformism can often negatively affect local residents, disrupting their daily habits and endangering their tradition. In such situations it appears the feeling of harming traditional identity among the locals, which causes emotional attachment to their cultural aspects and customs that derive from the tradition (Koncul 2004: 211).

\section{MONTENEGRIN CULTURAL TOURISM AND TOURISM IN GENERAL- PROPOSALS FOR PROGRESS}

Montenegro has good conditions for development of all types of tourism, since it has beautiful beaches, mountainous region in the north, rich cultural heritage and well preserved natural environment. Montenegro was a well-known tourist resort during the 1980s, but because of the wars waged in the surrounding states during the 1990s, its image of a tourist destination was tarnished. Montenegrin tourism did not begin to recover until the early 2000s, and since then the number of tourists and overnight stays has increased significantly. Almost all of Montenegro's economic activities are focused on tourism development. The Government of Montenegro has set itself the goal of developing Montenegro into an elite tourist destination.

Image 1. Montenegro location

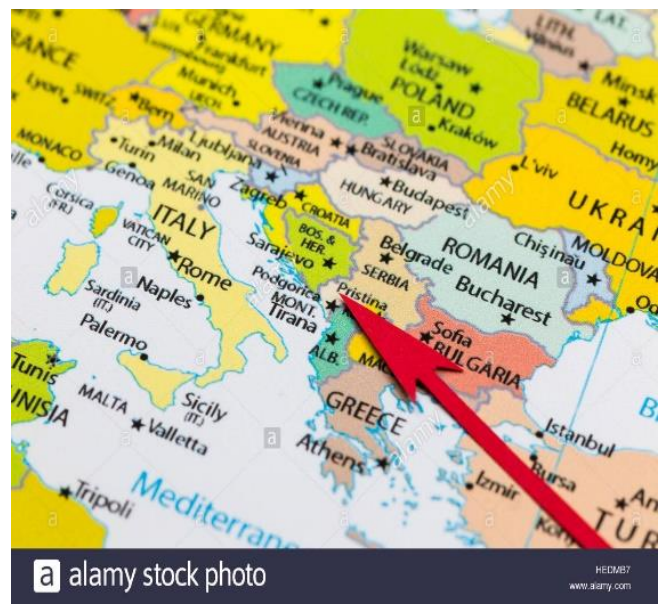

Source: https://www.alamy.com/stock-photo-red-arrow-pointing-montenegro-on-the-map-of-europecontinent-129379131.html

Tourism in Montenegro today, directly and indirectly, accounts for over 25\% of GDP (social gross product). What should be mentioned at the beginning is that Montenegrin tourism takes place for several months during the year - therefore, it is not actual throughout the year. In order to overcome this, it is also necessary to respond to some of the challenges such as: the development of infrastructure and human resources that is conditioned by market growth; the rapid development of client needs; the need to develop new markets and new products, etc. To have a better insight into the state of tourism in Montenegro, it is good to mention some figures. Namely, the registered accommodation capacity is about 120,000 beds. However, a large number of apartments and holiday homes are not registered for the provision of tourist accommodation, but it is issued. Consequently, MONSTAT estimates that the real figure reaches up to 300,000 beds. The problem that occurs in people who bypass the registered issuance of their homes for tourists is projected to reduce transparency, which directly affects the lower supply and lower earnings for caterers (URL - 3, 2008). Next we will see that since 
independence in 2006, Montenegro has benefited from tourism in the first two years. Of course, this does not imply that independence has contributed to the development of tourism, but has played a significant role. This is presented in Figure 1 presented by the Ministry of Tourism and Environmental Protection of Montenegro in the Tourism Development Strategy of Montenegro until 2020.

Image 2. Montenegro location

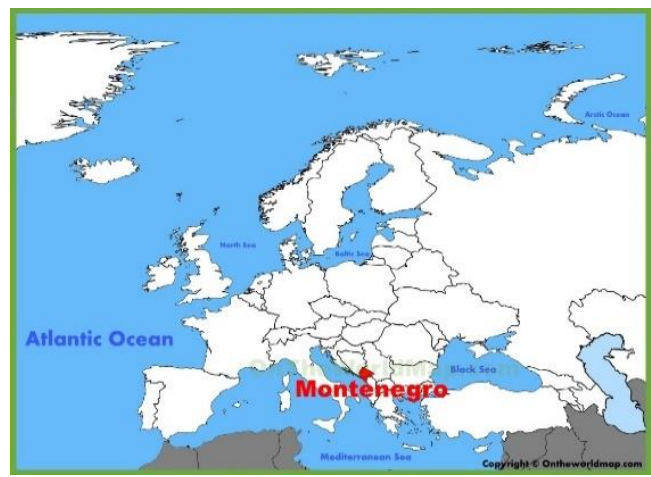

Source: http://ontheworldmap.com/montenegro/montenegro-location-on-the-europe-map.html

Figure 1: Policy set by the Government of Montenegro for 2007

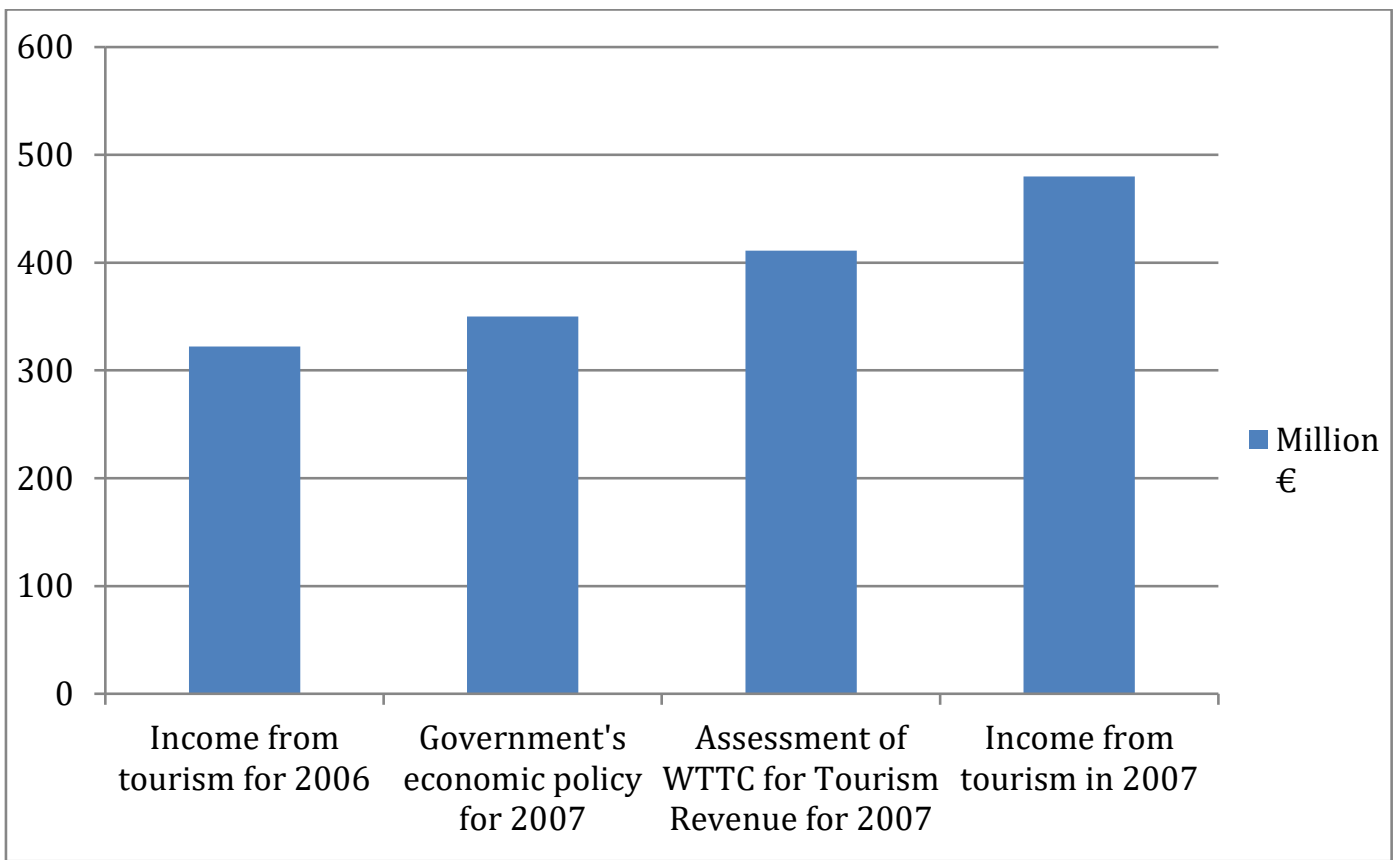

Figure 1 shows the forecast and policy set by the Government of Montenegro for 2007, and on the other hand, we see the assessment of the World Travel and Tourism Council. According to the Government, our country is supposed to earn 350 million euros from tourism in 2007, while the previously mentioned WTTC said that numeral will rise to 411 million euros. In the end, the achieved result was 480 million euros, which exceeded all estimates and turned out very affirmatively for the tourism of Montenegro (URL - 3, 2008).

Furthermore, the preview of tourism in Montenegro is supported by a well-known method. The SWOT analysis provides qualitative data that makes it possible to make strategically important decisions.

On the basis of the collected and available informations, the SWOT analysis of Montenegro as a tourist destination was made, presented in Table 1. 
Table 1: SWOT analysis of Montenegro as a tourist destination

\begin{tabular}{|c|c|}
\hline Strengths & Weaknesses \\
\hline $\begin{array}{l}\text { - Broad offer in a small space } \\
\text { - Climate and geographical position } \\
\text { - Natural values } \\
\text { - Cultural - historical heritage } \\
\text { - Traditional recipes - food and drink } \\
\text { - Favorable ambience for foreign investors } \\
\text { - Good relations with countries from the region } \\
\text { - Various cultural events and manifestations } \\
\text { - The tradition and continuity of the festivals and } \\
\text { other events }\end{array}$ & $\begin{array}{l}\text { - Insufficient accommodation capacities } \\
\text { - Lack of awareness of the importance of tourism } \\
\text { - Lack of qualified staff to work in tourism } \\
\text { - Low level of service quality } \\
\text { - The impurities of the beaches } \\
\text { - Inadequate supporting infrastructure (water supply, } \\
\text { road infrastructure and parking) } \\
\text { - Lack of areas with the status of protected area in } \\
\text { coastal areas } \\
\text { - Insufficient offer of cultural events and festivals out } \\
\text { of season } \\
\text { - Insufficient use of existing heritage values in the } \\
\text { development of cultural tourism } \\
\text { - The focus of cultural content on the local audience } \\
\text { - Lack of networking cultural and tourist entities } \\
\text { - Lack of innovation in the creation of cultural tourism } \\
\text { programs } \\
\text { - Unattractive promotion (poor visual solutions) } \\
\text { - Overlapping events and manifestations }\end{array}$ \\
\hline Opport & Threats \\
\hline $\begin{array}{l}\text { - Growth of international demand for tourism } \\
\text { oriented towards nature } \\
\text { - Current integration in the EU } \\
\text { - Development of regional tourist centers } \\
\text { - Private - public partnership } \\
\text { - Openness for cooperation with renowned artists } \\
\text { and experts from the world } \\
\text { - Membership in international associations } \\
\text { (MEDCRUISE - the Association of } \\
\text { Mediterranean and adjoining seas cruise ports) as } \\
\text { an opportunity to promote the cultural elements of } \\
\text { the destination }\end{array}$ & $\begin{array}{l}\text { - VAT increase } \\
\text { - Increase in transport costs } \\
\text { - The impacts of climate change } \\
\text { - Unplanned construction } \\
\text { - Poor traffic infrastructure } \\
\text { - Lack of necessary equipment to respond to weather } \\
\text { disasters } \\
\text { - Deficit of the beach area with public property status } \\
\text { - Nonfunctionality of certain cultural heritage objects } \\
\text { - Lack of cultural infrastructure in case of bad weather }\end{array}$ \\
\hline
\end{tabular}

From the SWOT analysis of Montenegro as a tourist destination, we can see that, when it comes to strengths, the most important things to single out would be a wide range of services in a small area; climate and geographical position of the country; and the tradition and continuity of the festivals and other events. Namely, the ability to stay on the mountain from which the sea is distant for some two hours of driving is rare feature of any country in the world, which rank us as one of the first destinations that have this privilege.

Thanks to its geographical position the climate of Montenegro is very varied Mediterranean in the south, moderate-continental in basins and valleys and mountain climates (URL - 4, 2014). Regarding the tradition and continuity of holding the festivals and other events, Montenegro has a very rich repertoire that has established growth intensity for years and is gaining an increasingly important place in the region. Here, among other things, are included: Bar Chronicle, Music Days, Sun Scales, Sailing Regatta, Cetinje Cultural Summer, Durmitor Ring, etc (URL - 5, 2015).

The most important factors that point to the weakness of the Montenegrin tourist brand are the insufficient accommodation infrastructure, the lack of awareness of tourism for the purpose of valorisation of tourist resources, as well as the insufficient offer of cultural events and events out of the season. That Montenegro is deficient in the case of accommodation capacities during the season, is confirmed by the fact that the National Tourism Organization 
of Montenegro, in its Program of Work for 2017, identified this as one of the most significant problems to be faced as soon as possible. Namely, this problem is a limiting circumstance for Montenegrin tourism and directly affects the strengthening of competition and the weakening of the position of the Montenegrin destination at the international level (URL - 2, 2018). The built consciousness of the caterers on the significance of tourism is very important and represents one of the crucial preconditions for the long-term survival of this branch of economy. The aim is that tourists are staying in a friendly and homely atmosphere with flexible prices, not local caterers to come to quick profits that will provide tourism in Montenegro for a short period of time. In the end, local tourism organizations have to make a greater offer of cultural events and events out their seasonal programs in their work programs, because in this way they strengthen their position among the competitive countries and create the possibility for potential growth of tourist inflows throughout the year.

In the third element of analysis, one of the main potentials is the development of regional tourist centers. Here, it is understood that Montenegro, in the context of tourism, is positioning itself as a leading country among its neighbors. It is also worth mentioning the possibility of even more popularization of our destination through accession to the European Union, where the borders, and the market, open to the whole of Europe. Given that Montenegro is a country of small capacities in relation to larger European countries, its accession to international organizations, such as MEDCRUISE (the Association of Mediterranean and adjoining seas cruise ports), is very important in order to promote it as an attractive cultural destination. It is important to note here that port Kotor is a member of this organization, which does not mean that it should be stopped and left by the side of port Bar, as well as other ports of the Montenegrin coast (URL - 1, 2018).

It seems that the threat to which we should pay the most attention is unplanned construction - especially the Montenegrin coast. Montenegro, in a tourist context, has the potential to stand out itself from other destinations by applying a clear and concise vision of its construction. Namely, a good urban plan is required, based on principles and excluded from any deviations. His constant changes, accompanied by the material exploitation of individuals, create city chaos and disorder, which is not a permanent and coexistent solution for the continuous progress of tourism in Montenegro. What is very important here to mention refers to the often VAT increase. This requires a price increase at the state level, and if prices are higher every year, and tourists will be less.And finally, the revaluation of one part of the cultural heritage would enrich the cultural corps provided to tourists and raise the level of cultural appeal and attractiveness.

\section{CONCLUDING REMARKS}

In addition to the historical context of cultural tourism, the relation between the concepts of culture and tourism, the most attention is devoted to analyzing the situation of Montenegrin cultural tourism, as well as its importance for the Montenegrin economy at a given moment and in the future.

A matrix was shown through SWOT analysis, where the targeted content are deviant elements of Montenegrin cultural tourism, as well as the chances for further improvement, which is possible through the implementation of a policy of economic growth and development of Montenegro.

Based on the presented factors in Table 1, it was concluded that Montenegrin cultural tourism is in a relatively good and sustainable situation, whose further progress and prosperity can be realized through the application of adequate strategic moves that in the near future should be carried out as objectively implemented by the Ministry of Sustainable Development and Tourism. 


\section{REFERENCES}

Books:

GAČEV, G., 2011, Mentaliteti naroda sveta, Službeni glasnik, Beograd, ISBN: 978-86-5191130-2.

JELINČIĆ, D. A., 2008, Abeceda kulturnog turizma, MEANDARMEDIA, Zagreb, ISBN: 9789537355180.

KOMBOL PANČIĆ, T., 2006, Kulturno nasljeđe i turizam, Radovi Zavoda za znastveni rad Varaždin, Hrvatska, UDK: 008+338.48.

KONCUL, N., 2004, Položaj turizma u globalnim i europskim integracijskim procesima, Naše more (more i turizam), Dubrovnik, ISSN: 0469-6255.

PEROVIĆ, M. J., 1998, Menadžment, informatika, kvalitet, CIM Centar, pp. 147., Kragujevac, ISBN: 8680581305, 9788680581309.

RICHARDS, G., 1996, Annals of Tourism Research - Production and consumption od European Cultural Tourism, Elsevier Science, pp. 266, New York, ISSN: 0160-7383.

VUJOVIĆ, A., PEROVIĆ, M., KRIVOKAPIĆ, Z., JOVANOVIĆ, J., 2014, Industrijski inženjering, Mašinski fakultet Univerziteta Crne Gore, Podgorica, pp. 248, ISBN: 9789940-527-36-5.

VUKONIĆ, B., 2008, Povijesni gradovi i njihova turistička razvojna opcija, Acta Turistica Nova, Zagreb, pp. 111 - 122, ISSN: 03534316.

\section{Web pages:}

URL - 1 MEDCRUISE - The Association of Mediterranean Cruise Ports, 2018, Port Members - Kotor (Main informations) [online], Santa Cruz de Tenerife, http://www.medcruise.com/port-members, [Date Accessed: 15 february 2020].

URL - 2 Ministarstvo održivog razvoja i turizma, 2018, Program rada Ministarstva održivog razvoja $i$ turizma za 2018. godinu [online], Crna Gora, http://www.mrt.gov.me/rubrike/spi/spi-planovi, [Date Accessed: 17 february 2020].

URL - 3 Ministarstvo turizma i zaštite životne sredine, 2008, Strategija razvoja turizma u Crnoj Gori do 2020. godine [online], Podgorica, http://www.bjelasica-komovi.me/wpcontent/uploads/2015/01/Strategija-razvoja-turizma-Crne-Gore-do-2020.-godine1.pdf, [Date Accessed: 17 february 2020].

URL - 4 Ministarstvo za informaciono društvo i telekomunikacije, 2014, Geografija - klima [online], Crna Gora, http://www.me/index.php/cg/geografija/klima, [Date Accessed: 10 february 2020].

URL - 5 Visit Montenegro (Breathtaking Beauty), 2015, Crna Gora-Manifestacije i festivali [online], Crna Gora, https://me.visit-montenegro.com/montenegro/events-andfestivals/7/, [Date Accessed: 11 february 2020]. 